\title{
POZNÁVÁNÍ VÝVOJE RESTAURÁTORSKÝCH TECHNIK KERAMIKY NA ZÁKLADĚ STUDIA NÁLEZOVÝCH DENÍKŮ Z VÝZKUMŮ NA PRAŽSKÉM HRADĚ
}

\author{
GABRIELA BLAŽKOVÁ - LJUBA SVOBODOVÁ
}

\begin{abstract}
Abstrakt: V archivu Archeologického ústavu AV ČR Praha, v. v. i., na pracovišti Pražský hrad jsou uloženy pracovni deníky, které detailné popisuji zpracováni keramických nálezů pocházejících z archeologických výzkumů realizovaných na Pražském hradě v letech 1925-1955. Při odborném studiu konkrétních nálezů ošetřených v minulosti lze s jejich pomoci názorně dokumentovat rozvoj keramické restaurátorské a konzervátorské profese a porovnat rozdilné př́stupy $k$ ochraně sbirkotvorných uměleckořemeslných předmětů. Početné keramické soubory dovoluji srovnat konzervačně-restaurátorské zákroky prováděné v minulosti a v současnosti. S úspěšně provedenými restaurátorskými zákroky je v současnosti neodmyslitelně spojena mezioborová spolupráce. Nezbytnou součásti kvalitně provedené restaurátorské práce je respektování etických kodexů restaurátora, které jednoznačně definuji způsoby a rozsah restaurátorských zásahů.
\end{abstract}

Klíčová slova: keramika - restaurování-konzervování-adheziva.

The development of pottery restoration techniques based on the diaries of finds from excavations at Prague Castle

Abstract: The archive of the Institute of Archaeology of the Czech Academy of Sciences, Prague, the Prague Castle department holds work diaries describing in detail the processing of pottery finds yielded by archaeological research conducted at Prague Castle in the years 1925-1955. Specialist study of particular finds restored in the past helps to document the development of pottery restoration and conservation and to compare different approaches to the protection of arts and crafts objects in museum collections. Large pottery series enable the comparison of conservation and restoration procedures in the past and at present. Successful restoration procedures are now closely linked with interdisciplinary collaboration. An integral part of quality restoration work is the following of ethical codes which define the manners and extent of restorers' interventions.

Key words: pottery - restoration - conservation - adhesives.

\section{Úvod}

Každý obor lidské činnosti se vyvíjí a má svou historii. Na keramických nálezech ošetřených v minulosti lze velmi názorně dokumentovat rozvoj keramické restaurátorské profese a porovnat tak rozdílné př́stupy $\mathrm{k}$ ochraně sbírkotvorných uměleckořemeslných předmětů. Četnost keramických nálezů dovoluje srovnávat vlastní konzervačněl-restaurátorské ${ }^{2}$ zákroky prováděné v minulosti a současnosti. Starší zásahy se staly součástí ošetřených keramických artefaktů. $\mathrm{V}$ některých případech je vhodnější respektovat rukopis konzervátora-předchůdce, tedy původní filozofii restaurování, než opětovně namáhat artefakt a zvyšovat riziko jeho poškození či riskovat zničení originálního materiálu při odstraňování starých zákroků.

\footnotetext{
1 Konzervací předmětů (lat. conservatio, znamená stabilizování, zastavení) se rozumí zachování jejich hmotné podstaty, kde není podmínkou vrátit předmět do původního stavu. Všeobecně platí, že konzervovat předmět znamená zachovat jeho stávající stav. V rámci konzervačního procesu jsou odstraněny povrchové nečistoty a škodlivé korozivní složky, prŕípadně je provedena stabilizace nalezeného materiálu.

2 Restaurováním předmětů (z latinského restauratio) se rozumí ošetření předmětu za účelem obnovení původního stavu. Keramické nálezy se navracejí do známého či předpokládaného stavu, často s přidáním neoriginálních pomocných materiálů. V praxi keramické laboratoře to znamená, že jsou vyhledány navazující spoje očištěných stř̌epů, které jsou následně slepeny do původního celku. Na slepeném plášti artefaktů se doplňují chybějíí místa vhodnou hmotou.
} 


\section{Restaurování a konzervování archeologických nálezů na počátku archeologického výzkumu na Pražském hradě}

Systematický archeologický výzkum zahájil Státní archeologický ústav na Pražském hradě dne 3. června 1925. Bylo to v souvislosti s rozsáhlou rekonstrukcí hradního areálu na sídlo prvního československého prezidenta Tomáše Garrigua Masaryka. V souvislosti s rozsáhlými terénními odkryvy přibývaly i archeologické nálezy, které se hned od počátku deponovaly v prostorách tomu určených přímo na Pražském hradě.

To, že archeologové z podstaty své práce shromažd'ují a dokumentují keramický střepový materiál, není překvapující. S hradními archeologickými soubory se však minimálně jedno překvapení pojí. Vztahuje se k roku 1925, kdy studium raně středověkého období bylo ve svých počátcích a do 50. let, kdy se v tehdejším Československu začala konstituovat středověká archeologie, chybělo více než 25 let. Již od samého počátku systematického výzkumu Pražského hradu vedoucí výzkumu, nejprve Jaroslav Pasternak a později Ivan Borkovský, shromažd’ovali i zdánlivě nezajímavé glazované stř̌epy. Faktem je, že tyto nálezy pocházely především z odpadních jímek, a bylo zřejmé, že je možné z nich sestavit celé nádoby, ale přesto je třeba vyzdvihnout prozíravost tehdejších archeologů působících na Pražském hradě.

Střepy se pouze nesbíraly, ale záhy se s nimi začalo pracovat. Práce v laboratoři se zaznamenávala do pracovních deníků. Nejstarší zápis je datován k 9. červenci 1926. V zápisech pracovního deníku je možné se dočíst, že pracovní pomůcky, které se v laboratoři používaly, byly totožné $\mathrm{s}$ těmi dnešními - kartáč, kartáček na zuby - s výjimkou materiálového složení těchto pomůcek. Na lepení a čištění nádob se používal klih, denaturalizovaný líh a kyselina solná. V denících jsou podrobně popsány postupující restaurátorské práce na jednotlivých keramických nálezech. V týdenních intervalech jsou vedeny podrobné záznamy o stavu a pokroku při rekonstrukci jednotlivých keramických nádob a kachlů, jež byly daný den ošetřovány. Na závěr každého dne byl zapsán přesný časový údaj, od kdy do kdy archeolog na souboru pracoval. Každá nádoba měla přiděleno inventární číslo, které se dochovalo dodnes a umožňuje tak sledování její proměny v čase. $\mathrm{V}$ denících se dá přesně vysledovat, kdy byly střepy čištěny za mokra, kdy byly tř́íděny dle barvy materiálu, glazury, vyhledávány podle okrajů, den, ornamentů a slepovány. K modelování chybějících částí nádob byl stejně jako dnes používán vosk. Části slepených nádob byly doplňovány sádrou, která byla dobrušována, aby bylo dosaženo požadovaného tvaru. Rekonstruované nádoby byly natírány klihem a následně formaldehydem. Špatné skladovací podmínky způsobovaly, že sádra $\mathrm{v}$ doplněných nádobách netvrdla a musela být nahrazena novou. ${ }^{3}$ Již v roce 1927 proběhla diskuse mezi stavitelem arch. Karlem Fialou a archeologem Ivanem Borkovským o tom, zda sádrové doplňky nádob barvit či nikoliv. Z Fialova pohledu mají tyto práce zatím čas.

Deníkové záznamy se nesoustředí pouze na popis rekonstrukce keramických nádob, ale jsou v nich popisovány všechny konzervované materiály - železné předměty, mince, kosti, kůže a dřevo. Díky těmto záznamům známe prostředky, pomocí nichž byly dané předměty stabilizovány.

Nemalé starosti působily hradním archeologům dřevěné sruby, které byly objeveny na III. nádvoří. Tato masivní dřeva velmi rychle podléhala zkáze. Nekonzervovaná totiž vysychala, drolila se a rozpadávala. Čištění a napouštění trámů se provádělo karbolinem. Vyzdvižené trámy pak byly napouštěny klihovou vodou (Deník 1927-1930, 1212).

Na útržku papíru vloženém do opisu pracovního deníku jsou uvedeny poznámky o konsolidačních roztocích a materiálech používaných ke konzervaci hliněných bloků, kostí a lebek s datem 15. VII.: „Hlína: napuštěna 50\% roztokem vodního skla (1 hrob silněji) / Kosti: napuštěny roztokem želatiny a formalínu (po té mořeny roztokem damara + mak. olej + benzín + terpentýn. / 9 lebek slepeno (dle možností, 2 vůbec nemožno sestaviti).“

3 24. 1. 1930: „Vyvětralá sádra v doplňovaných nádobách netvrdne. Sádra ležela dlouho v pytli na volném vzduchu, proto také není $k$ práci způsobilá. Strhuji proto tuto sádru z nádob minule doplněných a nahražuji novou." (Deník 1297-1930, 1213) 
Nálezy kožených bot z Kaple Všech svatých byly napouštěny lanolinem (Deník 1927-1930, 1205). Předměty ze železa a drahých kovů včetně šperků se čistily v destilované vodě a konzervovaly vařením v parafinu (Deník 1927-1930, 1190, 1192, 1196).

Těleso valu pod III. nádvořím bylo po vyčištění napouštěno vodním sklem a karbolinem (Deník 1927-1930, 1182). Skleněné předměty byly konzervovány zapponovým lakem (Deník 1927-1930, 1181).

Z deníkových záznamů vyplývá, že zaměstnanci archeologického výzkumu na Pražském hradě měli šestidenní pracovní týden. Nepracovalo se o nedělích a státních svátcích. Každý měsíc provedené práce a finanční výdaje kontroloval hradní stavitel architekt Karel Fiala, což od 6. prosince 1926 stvrzoval na konci každé stránky svým podpisem inkoustovou tužkou, stejně jako odsouhlasení nákladů. Kontrolu pravidelně prováděl i tehdejší ředitel Státního archeologického ústavu doktor Karel Buchtela a vedoucí archeologického výzkumu Pražského hradu v letech 1925-1942 doktor Karel Guth.

\section{Lidské zdroje}

Restaurování keramiky bylo obvykle považováno za snadný úkol, který může provádět s dobrými výsledky kdokoliv z ulice, bez odborného vzdělání, speciálního školení a tréninku. Keramiku ošetřoval většinou nekvalifikovaný personál. Neexistovaly odborné školy věnující se problematice restaurování ani odborná literatura. ${ }^{4}$ Ještě do nedávna si archeologové zpracovávali své keramické nálezy sami, což dokládá např́iklad soubor pracovních deníků z Pražského hradu Ivana Borkovského (obr. 1,2), který vedle vlastní odborné práce také fyzicky ošetřoval artefakty z nejrůznějších materiálů, at' už to byla keramika, sklo, kủže, textil, kosti lidské i zvířecí (včetně mytí, lepení lebek a celých koster) nebo dřevo (konzervace vědra, konve, okovu, trámů z III. nádvoří). Dr. Borkovský byl schopen konzervovat bronzové nebo železné předměty (včetně jejich odrezování v louhu a vyvařování v parafínu) i čistit a lepit kvádříkové zdivo (Deník 1930-1938, 1410). Dnes existuje celá řada akreditovaných odborných středních a vysokých škol, které mají velmi dobře nastavené učební plány s důrazem na odborné restaurátorské předměty. ${ }^{5}$ Studenti přicházejí do praxe vybaveni teoretickými znalostmi, ale i praktickými zkušenostmi v základní metodice konzervování a restaurování keramiky. Profesionální restaurátor, restaurátora keramiky nevyjímaje, by měl být majitelem tzv. „licence“- Povolení k restaurování kulturních památek, ${ }^{6}$ které uděluje Ministerstvo kultury ČR na základě vzdělání, odborné praxe, restaurátorských prací a celkového komisionálního posouzení schopností žadatele. Restaurátor keramiky musí mít cit pro ošetřovaný materiál a kombinovat jej s praktickými uměleckořemeslnými dovednostmi, podpořenými znalostmi chemie, historického a technologického kontextu.

\section{Etické kodexy}

„Etické kodexy tvoři rámec pravidel pro činnost restaurátorů, které poskytuji formálni zdůvodněni pro jejich práci, s cilem chránit objekty. Každý restaurátor má povinnost interpretovat kodexy a aplikovat je na konkrétni problém podle potřby. Neexistuji žádné definitivni odpovédi, proto nemohou být žádná pevná pravidla.“ (Oakley 2006, 47).7

\footnotetext{
4 K nejstarším českým literárním restaurátorským pramenům patří: Novotný 1894, 20; Čermák 1895, 96; Stocký 1927, sv. 1; Losos 1959, 169; Stránský 1976, 268; Págo 1985, 285; Zelinger 1987, 253; Josef 1994.

5 Vyšší odborná škola grafická a Střední průmyslová škola grafická v Praze vznikla v roce 1920. Restaurování keramiky se soustavně vyučuje od 80. let 20. století. Od roku 2005 existuje na Vysoké škole chemicko-technologické v Praze obor Konzervování a restaurování uměleckořemeslných děl ze skla a keramiky. Restaurování keramiky se také věnuje Střední škola umění a designu a Vyšší odborná škola Brno, př́ispěvková organizace, Masarykova univerzita v Brně a Slezská univerzita v Opavě.

6 Povolení Ministerstva kultury České republiky k restaurování kulturních památek dle Zákona o státní památkové péči č. 20/1987 v platném znění.

7 Etické kodexy, jež restaurátorská veřejnost v České republice nejčastěji přijímá (ač nejsou právně závazné), jsou uvedeny na konci příspěvku v př́loze.
} 

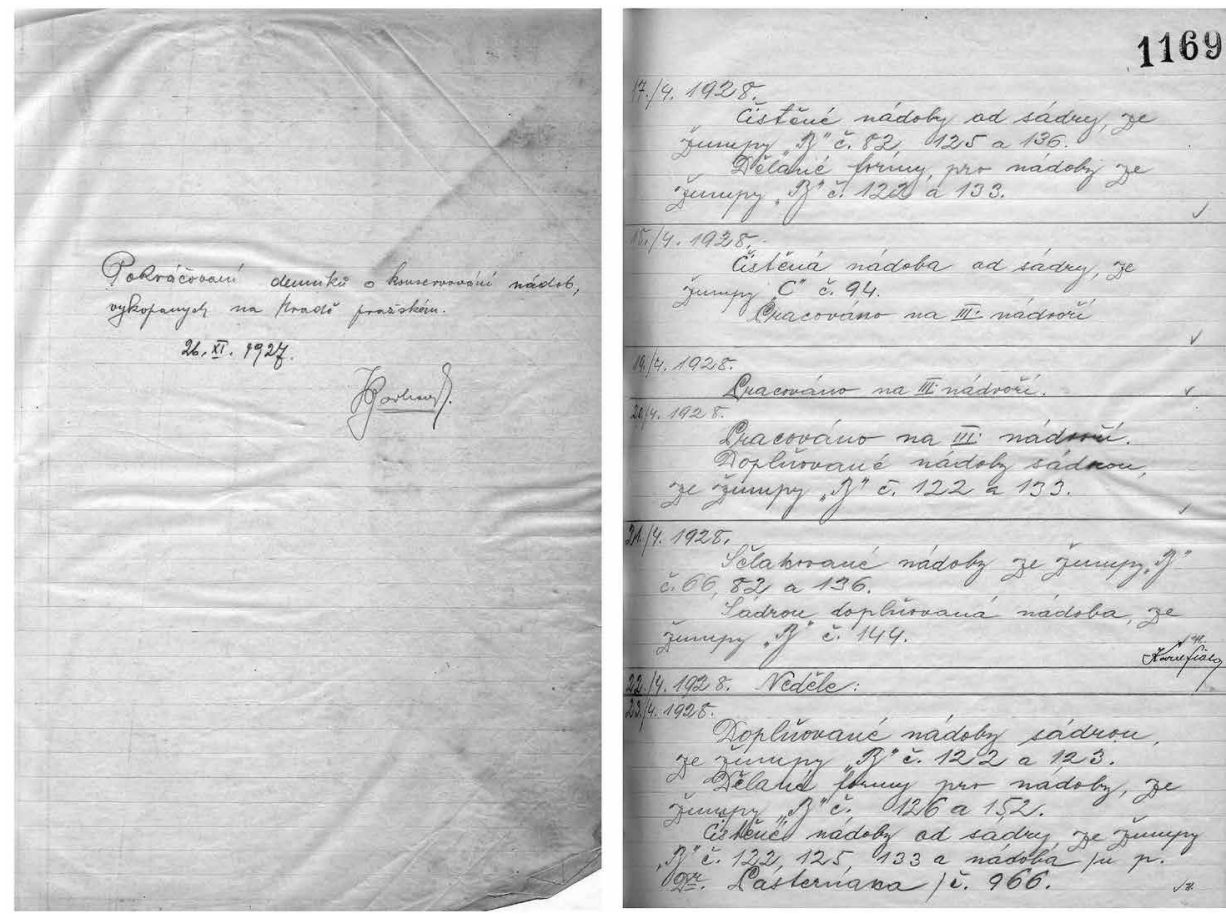

Obr. 1. Záznamy pracovního deníku z Pražského hradu (Deník 1927-1930). Foto L. Svobodová.

Abb. 1. Einträge in einem Arbeitstagebuch von der Prager Burg (Deník 1927-1930). Foto L. Svobodová.

Prvořadou povinností restaurátorů je keramiku ošetřit tak, aby se nezničila nebo nepotlačila její výpovědní hodnota a zachovala se pro příští generace. Prostor pro poškození objektu během intenzivních zákroků je značný. Většina etických kodexů proto zdůrazňuje, že zákroky by měly být omezeny na minimum. Žádný zákrok by neměl být proveden, aniž by byly nejprve posouzeny jeho dopady na ošetřovaný předmět. Pravidlo „čím méně, tím lépe“ se vztahuje i na intervenci vnesených reverzibilních ${ }^{8}$ materiálů. Restaurátor je povinen používat jen takové techniky a materiály, které - podle současných znalostí - neohrozí celistvost artefaktu a které se př́ípadně dají nejsnadněji a nejúplněji odstranit s minimální mírou rizika vůči původní hmotě artefaktu.

\section{Rozdíly mezi restaurováním keramických nálezů v minulosti a v současnosti}

\section{Exkavace nálezů}

V minulosti se restaurátor př́mo výkopových prací zpravidla neúčastnil. Vyzdvihování nálezů in situ probíhalo nejčastěji tak, že dělníci ve spolupráci s archeologem keramické nálezy obalili do hadrů, novin, tmelu vytvořeného z měkkého papíru a zředěného „bílého“ lepidla, ${ }^{9}$ bavlněných obinadel nebo sádrových obalů. Pro rozměrově náročnější objekty se vytvářela dřevěná bednění.

\footnotetext{
8 Dnes např́ič odbornou restaurátorskou obcí panuje shoda nad dodržováním principu reverzibility, respektive snadné odstranitelnosti použitých technologických zákroků a rozpustnosti vnesených materiálů (Svobodová 2013, 103). Dovedeno do extrému: kompletně zrestaurovaný exponát musí jít snadno a bez poškození vrátit do střepového nálezového stavu.

9 Většinou se jednalo o lepidla typu DISPERCOLL nebo HERCULES, která mají před vytvrzením vzhled mléčně bílé kapaliny.
} 

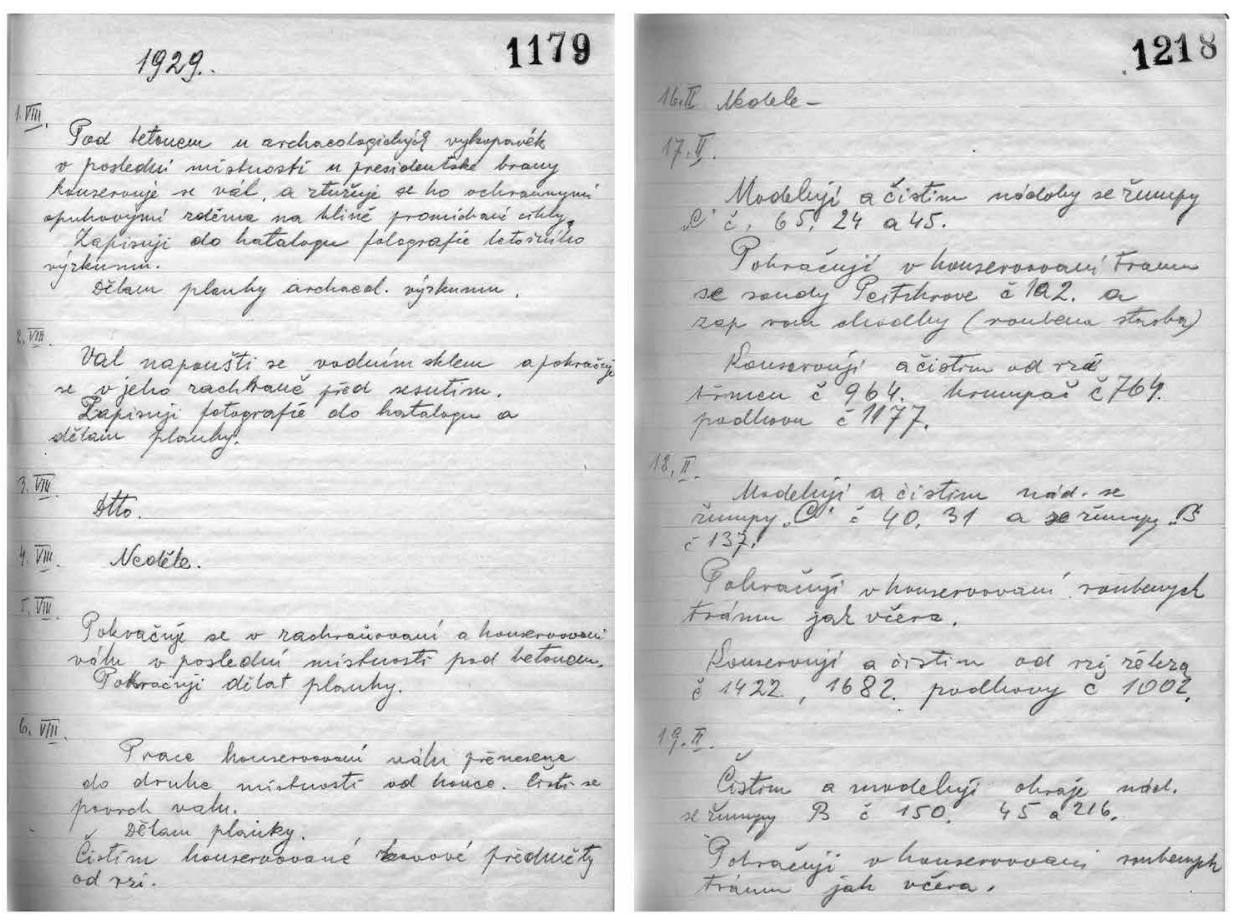

Obr. 2. Záznamy pracovního deníku z Pražského hradu (Deník 1927-1930). Foto L. Svobodová.

Abb. 2. Einträge in einem Arbeitstagebuch von der Prager Burg (Deník 1927-1930). Foto L. Svobodová.

Dnes není výjimkou, že restaurátor ${ }^{10}$ sleduje nálezové okolnosti přímo v terénu in natura a spolupodílí se na rozhodování o správném způsobu exkavace, odběru vzorků, případně na místě provede dočasnou konsolidaci předmětu ${ }^{11}$ jako preventivní opatření pro hladký transport do laboratoře k odbornému zpracování. Pro bandážování bezprostředně po exkavaci se používají potravinářské fólie, krepové pásky nebo nástřik PUR pěny ${ }^{12}$ přes fólii.

\section{Fotografická dokumentace}

Zásadním rozdílem v pracovním procesu restaurátora oproti minulosti je pořizování důkladné pracovní fotodokumentace. Ta se dříve vzhledem $\mathrm{k}$ absenci fotoaparátů a fotografického materiálu v keramických dílnách provádět nemohla a zainteresování profesionálních fotografů bylo nereálné. Při současné dostupnosti digitálních fotoaparátů je každý restaurátor zároveň i fotografem. Fotografie předmětu s měřitkem a barevnou škálou (ideálně ze všech pohledových stran) je základní nástroj dokumentace pro zachycení rozdílného stavu předmětu před, během a po vlastním restaurátorském zásahu. Každý jednotlivý zásah musí být zdokumentován nejen kvůli dalším budoucím zásahům, ale i jako podklad pro revizi všech učiněných kroků, na kterých je možno sledovat a kontrolovat, jak se předmět během ošetřování měnil. Fotografie jsou nedílnou součástí restaurátorských zpráv.

10 Keramické nálezy by se měly vybírat dřevěnými nebo plastovými nástroji. V žádném případě nejsou vhodné kovové nástroje typu krumpáče, lopaty, špachtle, dláta či lžíce, které mohou snadno povrch artefaktů poškrábat.

11 Na provizorní zpevnění keramických nálezů lze použít např. CYKLODODEKAN nebo IFES OH. Po aplikaci nástřikem se fixační látky samovolně vypaří v řádu několika dnů až týdnů.

12 Montážní polyuretanová pěna PUR ve spreji. Použivá se ve stavebnictví pro injektáže, k izolaci okenních a dveřních rámů, střech, kolmých stěn, podlah, ale také k vyplňování dutin (ledniček, mrazáků, bojlerů) a spár. 


\section{Komplexní restaurátorský průzkum}

V minulosti se rekognoskace keramických nálezů neprováděla. K restaurování se prristupovalo empiricky a na základě zkušeností. Dnes se před zahájením jakékoliv konzervátorsko-restaurátorské akce jako první krok zjišt’ují veškeré dostupné informace o ošetřovaném artefaktu, které se stávají součástí restaurátorských zpráv (Svobodová 2009, 28).

1) Restaurátorským průzkumem se zjišt’uje hmotná podstata ošetřovaného artefaktu, typologický popis, druh materiálu. Zjišt'uje se, jak, kde a kdy byl vlastní předmět vyroben, z jakých surovin, ${ }^{13}$ jakou technikou vytváření, včetně teploty výpalu, a v neposlední řadě $\mathrm{k}$ čemu sloužil, k čemu se používal, co se v něm přechovávalo, vařilo apod.

2) U artefaktů se zkoumá míra poškození, narušení, změn a ztrát. Diagnostikuje se stabilita, rozpustnost materiálu, typy, stupně a lokalizace povrchového znečištění. Zjištují se případné předchozí zásahy a úpravy. Zjištěné výsledky jsou podkladem pro volbu správné strategie a rozsahu konzervování, př́ípadně restaurování a sledu jednotlivých zásahů.

3) Průzkumem se odhalují dostupné informace, které keramický materiál nese. $\mathrm{Na}$ površích keramických artefaktů se hledají negativní otisky struktur nejrůznějších materiálů, jako jsou textil, kov a dřevo, které vznikly náhodně před vypálením keramické hmoty. Jde převážně o otisky šňůr, sítí, látek sloužících k zavěšení či drobné manipulaci s keramickým výrobkem. Studují se neúmyslné či záměrné otisky nástrojů používaných během vlastního vytváření či plastické výzdoby (hladítka, špachtle, struny pro odřezávání, škrabky, jehly atp.). Poměrně novou disciplínou je studium otisků prstů na artefaktech (obr. 3).$^{14}$ Pátrá se po stopách užíání, mezi něž patří fyzické opotřebení artefaktů na stěnách a nožkách, ale i po dokladech použití, jako jsou např́iklad zbytky potravin uvnitř nádob a potravinové skvrny. ${ }^{15}$ Dochované výplně nádob jsou velmi důkladně zkoumány a $\mathrm{v}$ rámci interdisciplinárního studia analyzovány.

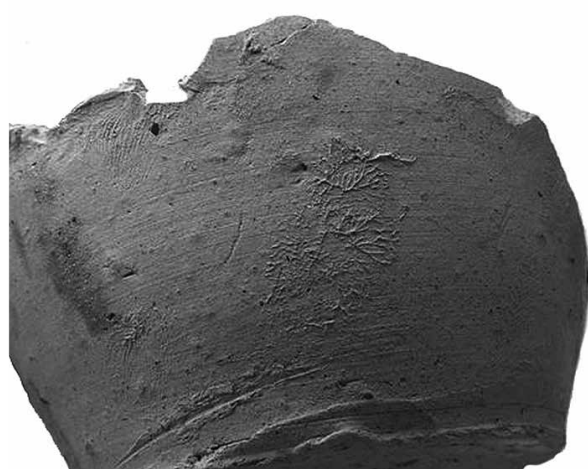

Obr. 3. Otisky prstů na hrnku, Praha - Hrad, odpadní jímka $S$, přír. č. 2823, inv. č. 55. Foto L. Svobodová.

Abb. 3. Fingerabdrücke an einem Topf, Prag - Burg, Abfallgrube S, Zuwachsnr. 2823, Inv.-Nr. 55. Foto L. Svobodová.

13 Moderní metody hodnocení keramických materiálů nabízejí poměrně širokou škálu možností, jak získat z archeologického nálezu keramiky co nejvíce poznatků. Mikroskopické pozorování mikrostruktury a minerálního složení krystalické fáze střepů i rentgenografické analýzy umožňuji důkladnější poznání keramické technologie dané doby v daném regionu. Chemické složení střepových hmot a glazur se analyzuje pomocí rentgenové fluorescenční analýzy (XRF). Mineralogické složení střepových hmot a glazur lze určit pomocí rentgenové difrakční analýzy (XRD). Infračervená spektroskopie (IF) identifikuje organické stopy (usazeniny) uvnitř nádob. Ramanova spektroskopie se používá k identifikaci povrchových úprav (důkaz tuhování, pigmentů, hlinek). Plynová chromatografie se používá k identifikaci zbytků potravin na keramických střepech. Radiografie - pomocí RTG snímků se zjišt’ují vnitřní konstrukce plastik, lokalizují se praskliny, zkorodované oblasti. U nádob in situ se ve výplni zjišt’uje př́itomnost kovových artefaktů, případně dalších předmětů. Počítačová tomografie (CT) se použivá zejména při průzkumu obsahu dutých předmětů, kdy lze pozorovat vzájemnou polohu jednotlivých předmětů ve výplni apod.

14 Paleodermatoglyfika studuje celé, ale i částečné otisky lidské tkáně na artefaktech, např. nehtové vrypy, otisky chodidel atp. Snaží se tak (nejčastěji na keramice) určit: 1) základní biologické atributy lidí, kteří své otisky na předmětech zanechali: odhad věku (do dospělosti), pohlaví, výšku postavy; 2) jejich choroby; 3) základní naznačení etnických vazeb (za podmínky dostatečných souborů otisků); 4) otisky mohou vypovídat o způsobu uchycení nádoby během modelace a posledních fázích výroby - manipulaci s ještě nevypálenou nádobou (Králík 2004). $15 \mathrm{Na}$ vnitřní straně střepů (často ve spárách porézních hmot i glazur, protože potraviny prosakovaly a vstřebaly se do těla nádoby) a na dně lze najít zbytky připáleného jídla, potravin, př́íškarky, napáleniny, stopy obsahu nádob (sůl) a produkty jejich rozkladu. Zbytky potravin se mohou vyskytovat zejména u nádob určených na vaření nebo na skladování zásob. Přítomnost sazí na vnějších stranách dokládá použití nádob při vaření na otevřeném ohni. 


\section{Konzervátorský a restaurátorský záměr}

Restaurátor má dle § 14, odst. 10 zák. č. 20/1987 Sb., v platném znění, a § 10 vyhlášky č. 66/1988 Sb., v platném znění, závaznou povinnost před vlastním restaurováním vypracovat tzv. restaurátorský záměr vycházející z provedeného předběžného restaurátorského průzkumu. V podstatě se jedná o zdůvodnění veškerých zamýšlených zákroků, které restaurátor plánuje udělat v rámci řetězce péče o artefakt, a to včetně specifikace zamýšlených použitých př́strojů, nástrojů a pomocných materiálů. Zadavatel restaurování musí být seznámen s koncepcí pracovního návrhu a technologického rámce restaurování a odsouhlasit jej vlastním podpisem. Restaurátor se zavazuje pracovat pouze $\mathrm{v}$ mezích určených záměrem. Nicméně v prŕípadě pozdějšího zjištění zásadně nových informací lze po dohodě se zadavatelem záměr doplnit nebo modifikovat.

\section{Čištění keramických nálezů}

Základní způsob odstraňování povrchového znečištění, tj. čištění mokrou cestou, se během uplynulých desetiletí nezměnil. Čistá kohoutková voda byla a je základním čisticím prostředkem, stejně tak kartáčky na zuby a na ruce jsou nenahraditelnými pomocníky i dnešních konzervátorů. Mění se pouze etický náhled na čištění, nebot' to není technicky reverzibilní. Odstraněnou hmotu již nelze vrátit. To je důležité z toho důvodu, aby si konzervátor byl jist, že „balast“, který hodlá odstranit, není originální součástí ošetřovaného artefaktu. Zvolením nevhodné technologie čištění mohou vzniknout nevratné ztráty. I opatrné otírání povrchu střepu může způsobit nenávratné zničení zbytků jemných stop nestabilní povrchové dekorace, inkrustace, nástřepí, tuhování a pigmentů. Cílem čištění nemá být, aby předmět vypadal jako právě vyrobený.

\section{Chemické metody čištění}

Posláním restaurátorů je uvést keramické nádoby do pokud možno lepšího stavu, než v jakém byly nalezeny, a přitom dbát na to, aby cokoliv, co bylo s nádobou provedeno, bylo možné snadno vrátit zpět. Jedním z mnoha cílů restaurování je získávat informace $\mathrm{z}$ keramických nálezů v rámci současných, ale i budoucích výzkumných záměrů, tzn. střepy ošetřit tak, aby si zachovaly co nejvíce původních vlastností. Kontroverzně proto neustále vyznívá téma odstraňování solných výkvětů, které patří mezi nejvýznamnější znečištovatele keramických povrchů. Některé restaurátorské školy dnes považují chemické čištění za neetické a neprofesionální, protože narušuje integritu keramiky. ${ }^{16}$ Ponořením střepu s vodou neodstranitelnou krustou ${ }^{17}$ na povrchu do lázně $\mathrm{z}$ kyseliny se můžeme připravit o možnost získání dalších, dnes třeba ještě nepoznaných relevantních informací. Těmito úvahami se dříve nikdo nezabýval a bývalo poměrně rozšířeným pravidlem veškerý keramický materiál nejčastěji ponořit do roztoku kyseliny chlorovodíkové18 (obr. 4) nebo roztoků fosforečnanů ${ }^{19}$ proto, aby byly střepy dokonale zbaveny veškerých nánosů, skrývajících detaily a znesnadňujících identifikaci typologických střepových znaků, jako jsou vzhled, barva, kvalita, struktura povrchu, druh výzdoby apod. O tom, zda byla po chemickém způsobu čištění provedena důkladná neutralizace (Svobodová 2009, 31), ${ }^{20}$ můžeme pouze spekulovat. Dnes existuje poměrně

\footnotetext{
16 Často je diskutováno, že keramický materiál je chemickým čištěním „oslaben“. Chemikálie pronikající do struktury materiálu keramiku značně degradují a dochází ke změnám v jejím složení. Působení kyselin nejméně odolává skelná fáze keramických materiálů a glazované povrchy, především nízko tavitelné vysoce olovnaté glazury.

17 Krusty, výkvěty, sintry, cicváry - povrchová znečištění vápenaté povahy $\left(\mathrm{CaCO}_{3}\right)$, se kterými nebyly předměty vyrobeny, ale získaly je většinou následně v souvislosti s kontextem uložení, vlivem okolního prostředí. Výkvěty vápenatých solí připomínaji svými tvary zkamenělé květiny, ledové vločky, jinovatku, minerální pavučinky, ale mohou být i ve formě enormně ztvrdlé kůry nebo hlízovitých shluků. Zabarvení je mléčné až nažloutlé dle mineralogického složení spodních či povrchových vod.

18 Většinou se vedle kyseliny chlorovodíkové (3-10 \%) na odstraňování znečišt'ujících nánosů používala i kyselina dusičná, trihydrogenfosforečná, octová, mravenčí, št’avelová nebo sírová.

19 Hexametafosforečnan sodný, fosforečnan draselný.

20 Na závěr čištění jakoukoliv chemikálií je třeba řádně vyplavit všechny její zbytky dokonalým několikanásobným promýváním a opláchnutím stř̌epů pod tekoucí vodou v kombinaci s máčením v lázni, aby na střepu došlo k dosažení neutrální hodnoty pH (hodnota 7; Svobodová 2009, 31).
} 


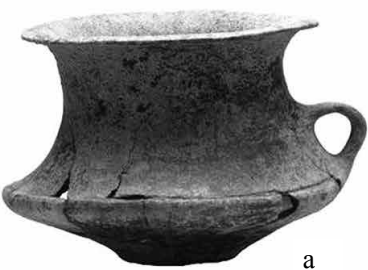

a

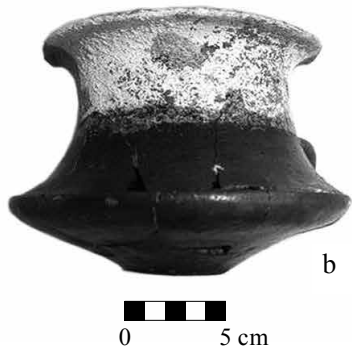

b

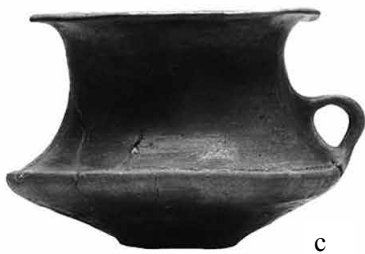

c

Obr. 4. Odstraňování solných výkvětů kyselinou chlorovodíkovou. a - před zásahem; b-během ponoru; c-po oplachu. Foto L. Svobodová.

Abb. 4. Beseitigung von Salzausblühungen mit Chlorwasserstoffsäure. a - vor dem Eingriff; b - während des Tauchbades; c-nach dem Abspülen. Foto L. Svobodová.

mnoho odborné literatury upozorňující na nebezpečí chemického čištění keramického materiálu (Bekić 2011, 94; Rodgers 2004, 214; Cronyn 2001, 326; Sigel-Koob 1997, 98-115; Scottoni [online]), a proto by se mělo používat jenom v nejnutnějších případech, a to pouze lokálně, např́iklad na hranách, když nelze střepy sesadit a slepit v přesné poloze.

\section{Lepení střepi̊}

Základní postup lepení střepư ${ }^{21}$ se nezměnil, i když lze předpokládat, že každý restaurátor měl a má i dnes svůj vlastní postup (obr. 5). Co se však zcela určitě změnilo, jsou používaná lepidla adheziva. Ještě v nedávné době byl trh s lepidly velmi omezený, a proto si je restaurátoři velmi často připravovali sami. Některá archaická adheziva jsou z dnešního pohledu hodně kuriózní a již se neaplikují, protože nesplňují základní kritéria pro ošetřování sbírkotvorných předmětů. ${ }^{22}$ Jedním z velkých nedostatků „domácích“ adheziv byla jejich malá pevnost, nahrazovaná přehnaným množstvím naneseným na hrany, vytvářejícím nevzhledné přetoky. K nejrozšířenějším patřila organická adheziva rostlinného původu, jako jsou klihy, ${ }^{23}$ želatiny, škroby, ${ }^{24}$ dále př́rodní pryskyřice, ${ }^{25}$ klovatiny ${ }^{26}$ a kaučuková adheziva. ${ }^{27} \mathrm{Z}$ organických adheziv živočišného původu se nejvíce používal šelak, ${ }^{28}$ zvírecí klihy, kaseinová adheziva ${ }^{29}$ a adheziva z krevního albuminu. ${ }^{30}$ Mezi anorganická adheziva používaná v minulosti lze řadit sádru, cementy, vodní sklo a př́rodní asfalt. $Z$ novodobějších, komerčně vyráběných lepidel, dnes již nepoužívaných lze jmenovat

\footnotetext{
21 Lepení je nejlepší metoda spojování střepů. Umožňuje prostorové sestavení vyhledaných střepů, nezvyšuje hmotnost předmětu a nenarušuje jeho celkový estetický vzhled.

22 Současná kritéria kladená na adheziva: rozebíratelnost lepeného spoje je klíčová otázka pro etické konzervování a restaurování; odstranitelnost lepidla v kteroukoliv dobu po jeho nanesení, a to vůči objektu maximálně šetrnými prostředky; životnost, stabilita a stálost spoje; stabilita adheziva po dobu 100 let (Newton-Davison 1989; Oakley-Kamal 2002); chemická stálost; pevnost lepených spojů; estetické vlastnosti; uživatelská přijatelnost a dnes velmi požadovaná šetrnost k životnímu prostř̌edí.

23 Klíh - archaický název pro lepidlo. Klihy se dělí podle použité zdrojové suroviny na rostlinné klihy - klíh vyrobený z větviček vinné révy, buku, vrby, ale také živočišné klihy, vyrobené vyluhováním kolagenu, obsaženého v živočišných produktech, jako jsou např. kosti, šlachy, nozdry, kopyta, podřadnější části kůží. Stejné je to u želatiny - rostlinná želatina je agar z mořských řas a živočišná želatina je z kolagenu, který je součástí tkání a chrupavek zvířat.

24 Škrob je př́rodní produkt získávaný z hlíz brambor a semen.

25 Borovicová, březová pryskyřice. Arabská guma je pryskyřice získaná z akátu. Damara je pryskyřice z damaroně bílé.

26 Klovatiny - gumy z ovocných stromů - tř̌šně, višně, švestky, meruňky.

27 Př́irodní kaučuk - vyměšovaný kaučukovníkem.

28 Šelak je pryskyřice živočišného původu, již vylučují samičky červce lakového na ochranu svých larev, parazitujících na některých druzích dřev, která rostou převážně v Indii a Thajsku.

29 Kasein je bílkovina obsažená ve všech druzích mléka.

30 Adheziva z krevního albuminu se prripravovala z krve jatečních zvířat, rozpuštěním ve vodě za př́idavku alkálií.
} 

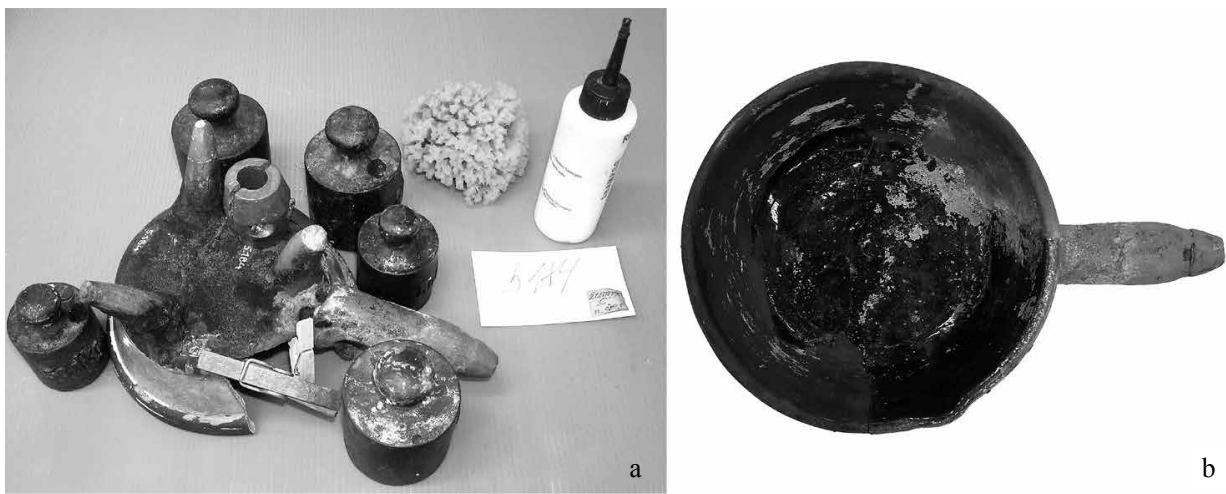

Obr. 5. Pracovní snímek restaurování trojnožky. a - během lepení; b- po restaurování. Foto L. Svobodová.

Abb. 5. Arbeitsaufnahme beim Restaurieren eines Dreifußes. a - während des Klebens; b - nach der Restaurierung. Foto L. Svobodová.

Resolvan, ${ }^{31}$ vteřinová adheziva, ${ }^{32}$ Dentacryl, Chemopren, Kanagom. Velkým problémem se ukazují být adheziva stále lepivá, jako jsou školní izolepy, které se nedají beze zbytku odstranit. I po několikanásobném působení rozpouštědel na povrchu střepu zůstávají lepivé plochy. V současnosti se k lepení keramických střepů používají komerčně dostupné syntetické polymerní materiály. Jsou to např́iklad vodné disperze polymerů, ${ }^{33}$ rozpouštědlové systémy, ${ }^{34}$ termoplastická ${ }^{35}$ a termosetová ${ }^{36}$ adheziva (Svobodová 2009, 36).

\section{Doplňování ztrát}

Doplňování ztrát v současnosti vychází z míry zachování originálu. Pro rekonstrukci celých předmětů je třeba nejméně $70 \%$ dochovaného pláště předmětu, na jehož základě se bude moci doklonováním doplnit zbytek těla (Svobodová 2009, 37; 2010, 33; obr. 6). ${ }^{37} \mathrm{~V}$ tomto objemovém množství musí být ideálně zastoupen celý profil nádoby, tj. celá výška a průřez ošetřovaného předmětu. Mezinárodní standardy jsou ještě př́ísnější a povolují doplňování, pouze v nezbytných prrípadech, např́íklad pro zajištění stability celého objektu, kdy lze k původnímu artefaktu doplnit nejvýše pět procent chybějících částí. Přitom nově vytvořené části musí být založeny pouze na existujících prvcích, a nikoliv na hypotetických rekonstrukcích. Restaurátor musí potlačit svou fantazii a kreativitu a pracovat pouze $\mathrm{v}$ rámci dochovaných mantinelů, jen v nezbytně nutné míře, a vše dokumentovat. V místech, kde není možné jasně identifikovat původní tvarosloví, nesmí být tvar doplňován. Vždy musí být patrné rozhraní mezi původním materiálem a novodobou výplní.

Před každým doplňováním se z preventivních důvodů natře okraj ztráty, či celý povrch slepeného předmětu tenkou vrstvou separačního nátěru (nejčastěji separátor zn. LUKOPREN),

\footnotetext{
31 Resolvan je průmyslově vyráběný celuloid rozpuštěný v acetonu.

32 Vteřinová je zastaralý název pro kyanoakrylátová adheziva. Dnes se nepouživají, protože představují vše, co nelze použít v restaurátorské praxi: stárnou a nejsou stabilní (Oakley-Kamal 2002, 69). Produkují křehký film, mají tendenci se loupat, ztrácí pevnost na světle, zhruba po 5-6 letech dochází $\mathrm{k}$ jejich degradaci.

33 Jde o lepidla (PVAc) s obchodním názvem např. DISPERCOLL D3, HERKULES, DUVILAX. Dle odborné literatury jsou ze všech polymerů, které jsou k dispozici v památkové péči, nejstabilnější (Svobodová 2009, 36; 2010, 32).

34 Jde o lepidla s obchodním názvem PARALOID.

35 Termoplastická, resp. tavná adheziva (EVA).

36 Termosetová adheziva, resp. epoxidové systémy. V památkové péči se nejvíce používají termosety s obchodním názvem ARALDIT 2020ß, Hxtal NYL - 1, EPO-Tek 301 .

37 Tvar pokladničky byl dobře čitelný. Dochovalo se dostatečné množství původního materiálu a ideální profil, proto se daly ztráty doplnit naklonováním dle zachovalých částí. Plošná ztráta v těle pokladničky byla přesně ohraničená a splňovala množstevní kritéria pro doplnění. Přesný otisk z neporušené oblasti předmětu - podkladová forma - umožnil reprodukci původního tvaru (Svobodová 2009, 37, 38; 2010, 33).
} 

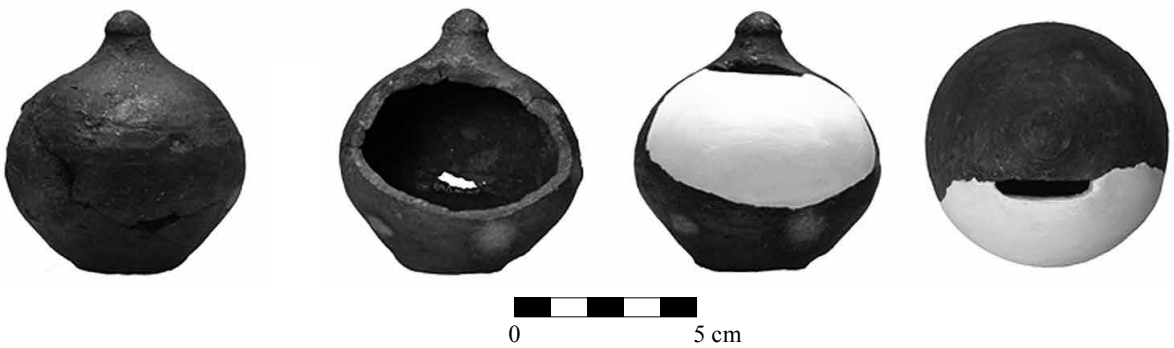

Obr. 6. Pokladnička před doplněním sádrové ztráty a po něm. Foto L. Svobodová.

Abb. 6. Sparbüchse vor und nach der Anstückung mit Gips. Foto L. Svobodová.

zajišt'ující ochranu keramiky před nechtěným znečištěním novodobým výplňovým materiálem (Svobodová 2009, 37; 2010, 33). V minulosti bylo naizolování originálních střepů podceňováno, nebo nebylo prováděno vůbec, případně se používalo našlehané jádrové mýdlo.

I v současnosti se pro doplňování náhrad u keramických nálezů použivá pro své vlastnosti sádra (Svobodová 2010, 33) ${ }^{38}$ a v menší míře epoxidové nebo rozpouštědlové systémy. ${ }^{39} \mathrm{~K}$ dobovým materiálům používaným na výplně, dnes klasifikovaným jako zastaralé, patřily také hliněné tmely, piliny smíchané s živočišným lepidlem nebo pryskyřicí, papírovina, přírodní vosky, cementové kaše, tmely z plavené křídy a modurit. Často je dnes nemožné analyticky stanovit, jaký druh výplně byl použit, protože kuriózní a nečekané materiály nejsou zastoupeny ve srovnávacích standardech. Mnoho výplňových směsí bylo „výrobním tajemstvím“. Výplně tak odrážejí historické trendy, stejně jako individuální důvtip. Výplně byly často opatřeny datem vzniku a vlastnoručním podpisem. Na druhé straně, dnes je naprosto nepřijatelné aplikovat metodu velmi rozšsiřenou ještě $v$ polovině minulého století, kdy střepy $\mathrm{z}$ jiných nádob sloužily $\mathrm{k}$ doplňování ztrát jinde (tzv. řešení ztrát s použitím prvků kanibalizace). Chybějící plochy se nahrazovaly zbylými střepy přiměřených velikostí z jiných nádob, vsazovaly a tmelily se jako mozaika do doplňovaného pláště. Výplňové střepy byly upravovány do požadovaných velikostí a tvarů rašplí. Tento pracovní postup je dnes absolutně nemyslitelný. V souladu s etickým kodexem se dnes př̀ řešení ztrát upřednostňují minimalistické tendence, na rozdíl od dob minulých, kdy se běžně vytvářely celé nádoby na základě jednoho malého střepu (obr. 7).

\section{Barevná retuš doplněných ztrát}

Restaurátoři se řídí pokyny zadavatele, zda barvit či nikoliv. Doplněné ztráty se mohou barevně sjednotit s původním barevným fondem (Svobodová 2010, 33) s ohledem na zásadu etického konzervování, tzn. doplňovaná místa mají být o stupeň světlejší, aby v detailním pohledu náhradní výplně zůstaly čitelné. Při pohledu z bezprostřední blízkosti musí být původně dochovaný materiál jasně rozpoznatelný od novodobých vysprávek (obr. 8). Restaurátor musí mít dostatečnou

\footnotetext{
38 Sádra je i dnes díky svým vlastnostem nejrozšiřenějším pomocným materiálem při restaurování. V případě nutnosti se dají sádrové výplně snadno odstranit mechanicky, vytlačením nebo za pomoci vody. Sádra se snadno rozdělává, lehce se s ní pracuje, spáruje, modeluje. Sádrová kaše po nalití do formy a po ztuhnutí kopíruje do všech detailů přesný tvar formy. Nevyvijí žádné nežádoucí chemické reakce vůči ošetřovanému materiálu, nemění jeho vzhled, vlastnosti ani strukturu. Sádrové implantáty výborně přilnou ke keramickým hranám. Po ztvrdnutí a vysušení sádrové výplně nezmenšuji objem, zachovávají a drži přesný tvar, jsou pevné, mají dokonalý celistvý, hladký, slinutý, úhledný povrch, jemnou strukturu a bílou barvu. Sádrové plomby velice dobře přijímají barvicí prostředky pro závěrečné barevné přizpůsobení, lze je barevně retušovat a patinovat. Po konečných povrchových úpravách povrch sádry opticky odpovídá charakteru povrchu keramiky. Sádra je finančně dostupná.

39 Tyto kompozitní systémy lze plnit dle barvy ošetřovaného exponátu např. pyrogenním oxidem křemičitým, mletým kaolínem nebo práškovými pigmenty. Plniva ovlivňují vzhled výsledné plomby (mat, barevnost atp.).
} 

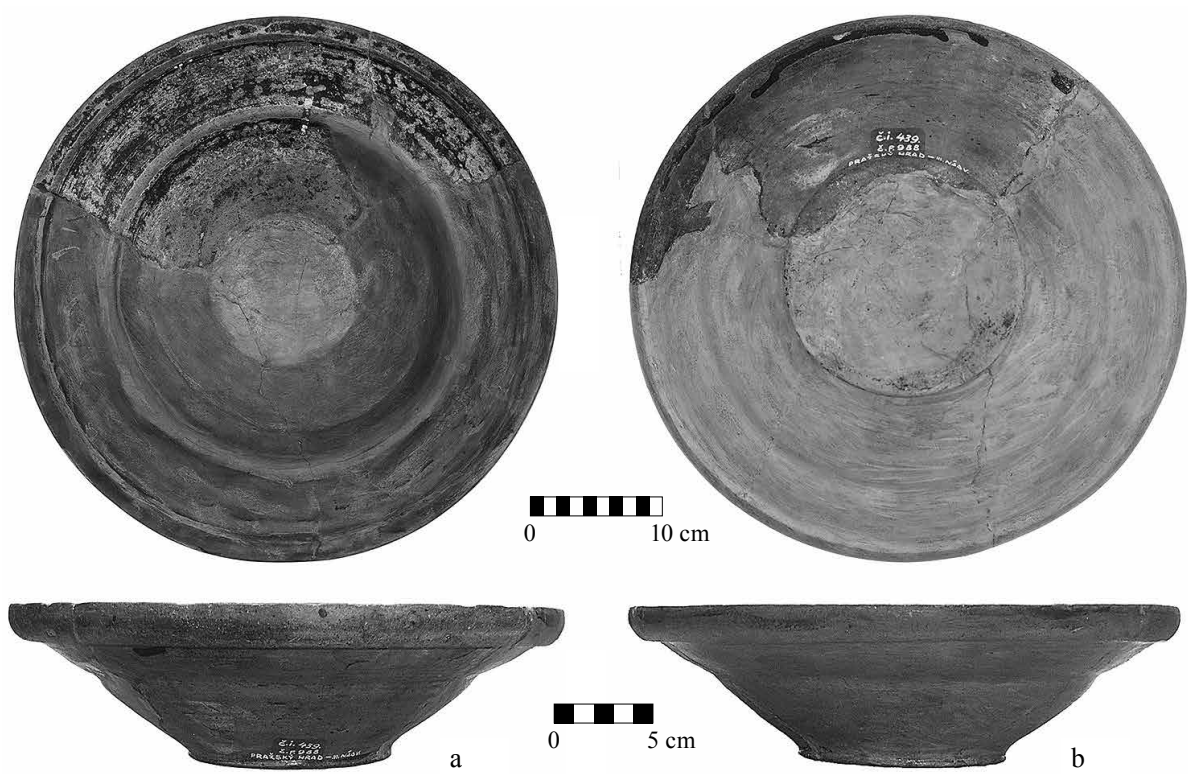

Obr. 7. Předimenzované sádrové doplňky u mělké mísy provedené ve 30. letech 20. století. a - avers; b - revers. Foto L. Svobodová.

Abb. 7. In den dreißiger Jahren des 20. Jahrhunderts an einer flachen Schale durchgeführte überdimensionierte Gipsanstückungen. a - Avers; b - Revers. Foto L. Svobodová.
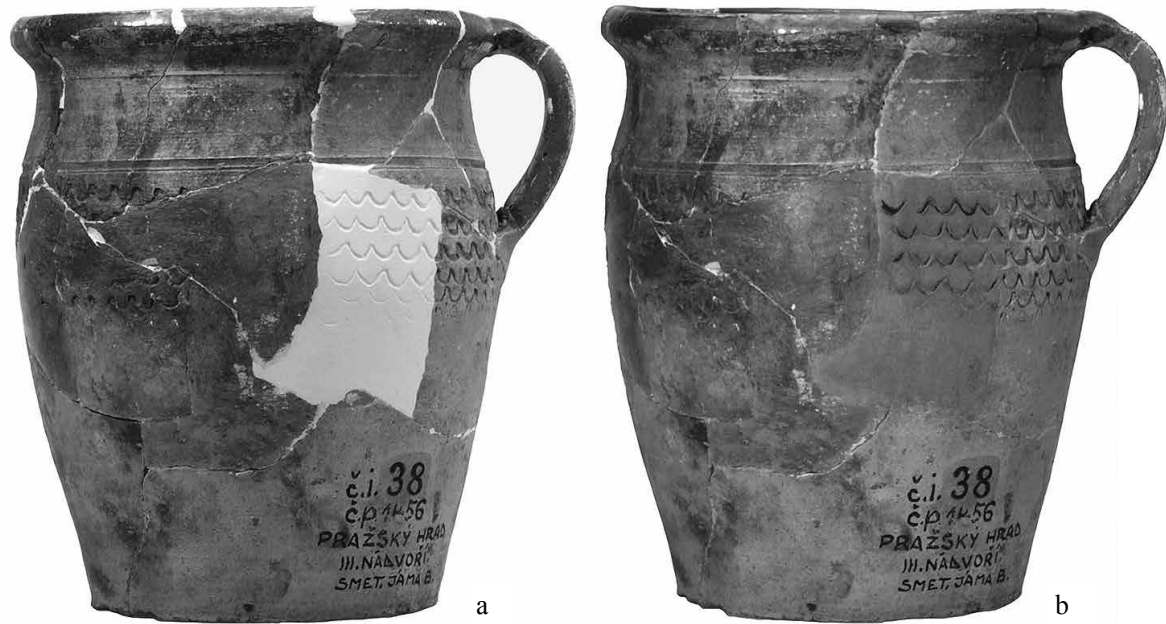

0

Obr. 8. Rekonstruovaná nádoba, Praha - Hrad, odpadní jímka B, prŕír. č. 1456, inv. č. 38. a - nebarvené sádrové výplně; b-po barevné retuši sádrových výplní. Foto J. Svobodová.

Abb. 8. Rekonstruiertes Gefäß, Prag - Burg, Abfallgrube B, Zuwachsnr. 1456, Inv.-Nr. 38. a - nicht gefärbte Gipsanstückungen; b - nach farblicher Retuschierung der Gipsanstückungen. Foto J. Svobodová. 


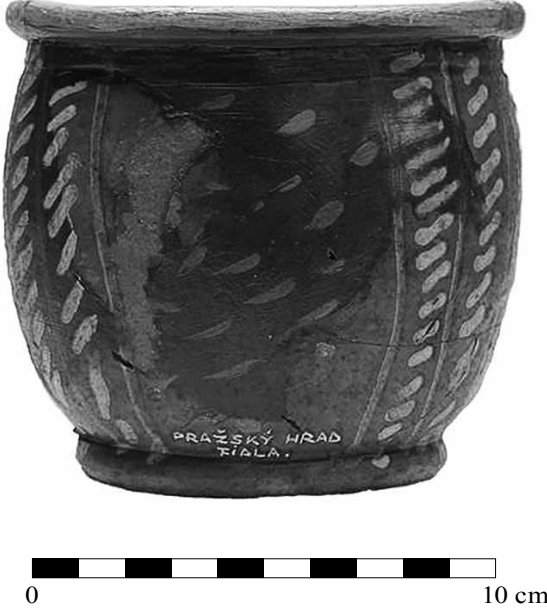

Obr. 9. Specifické řešení výzdoby na sádrovém doplňku u malované keramiky, tzv. berounského zboží, provedené v minulosti, Praha - Hrad, sbírka K. Fialy. Foto L. Svobodová.

Abb. 9. In der Vergangenheit durchgeführte spezielle Dekorlösung auf der Gipsanstückung einer bemalten Keramik, sog. Beroun-Ware, Prag - Burg, Sammlung K. Fiala. Foto L. Svobodová. vizuální schopnost, aby z pohledu na barvu originálu nejen viděl, ale také věděl, z jakých odstínů se skládá, jak ji namíchat.

$\mathrm{V}$ některých sbírkách se můžeme setkat $\mathrm{s}$ rušivě zvoleným barevným řešením sádrových výplní, které mají např́íklad zelený nebo fialový fond. Sádrové plomby se barvily a tónovaly šelakem, šlikrem, ${ }^{40}$ latexovými barvami, tušíi ${ }^{41}$ nebo práškovými pigmenty rozpuštěnými v ethanolu. Často se stávalo, že původní střepy byly potřísněny barvou použitou k nabarvení sádrových doplňků, která mnohdy přesahovala $i$ více než centimetr na keramické střepy a zabarvovala jejich hrany. Dokonce se celoplošně přetíraly veškeré vnitřní keramické plochy. V současnosti barva nesmí v žádném př́ípadě přesahovat na původní střepy, a proto se používají vodou snadno odstranitelné barvicí prostředky, ${ }^{42}$ které lze $\mathrm{v}$ př́ípadě potřeby šetrně a kompletně beze stop odstranit. Malované ornamenty, dekory a vzory se doplňují pouze tehdy, je-li stoprocentní jistota, jak ornament vypadal a jak navazoval (obr. 9).

\section{Dobové celoplošné zpevňování keramického pláště}

Dříve se celé nádoby z preventivních důvodů vylévaly sádrou. Slepené nádoby se zvenku fixovaly bavlněnými obvazy namočenými $\mathrm{v}$ šelaku, klihu, parafínu nebo ve voskových tmelech. ${ }^{43}$ Na střepy se mohly nanášet zpevňovací látky, jako jsou vodní sklo, klihová voda či želatina. $\mathrm{Na}$ sádrové výplně se nanášela fermež, ${ }^{44}$ včelí vosk, kravské mléko, kamenec, ${ }^{45}$ vápenná voda a šelak. ${ }^{46}$ Předpokládalo se, že nátěry zvýší soudržnost a pevnost nádob sesazených z jednotlivých fragmentů. Barvené i nebarvené výplně se patinovaly včelím voskem v terpentýnu nebo benzínu či parafínem rozpuštěným v benzínu, nebot' ty vytvářely ochrannou bariéru před vlhkostí. Z obav před napadením plísněmi se nádoby natíraly formaldehydem, ${ }^{47}$ roztokem modré skalice ${ }^{48}$ nebo kafrem..$^{49}$ Nebyla to však dobrá volba, nebot' penetrace vnesenými látkami v kombinaci s vyšší vlhkostí způsobuje degradaci, ztmavnutí keramiky i sádrových výplní, a taková konsolidace se velmi těžce odstraňuje. Celoplošné zpevňování lepením sesazených střepů a výplňového materiálu se již neprovádí, protože existencí depozitářů s regulovanými klimatickými podmínkami pro dlouhodobé uložení ztratilo smysl.

40 Hliněná (šlikrová) patina se připravovala rozmícháním hlíny - šlikru. Štětcem se natřela na suchou sádrovou plochu. Po uschnutí hlíny se přebytečná hlína otřela navlhčeným hadříkem.

41 Tuhování se simulovalo tak, že namletá tuha se rozdělala v octu na hustotu smetany. Hmota se štětcem nanesla na povrch sádrového odlitku a po zaschnutí vyleštila.

42 Akvarelové, temperové, akrylové barvy (Svobodová 2009, 38).

43 Do včelího vosku se přidávala kalafuna, cedrový balzám, damara, šelak, mastix a dnes blíže nespecifikovatelné pryskyřice.

44 Fermež je zahuštěný lněný olej.

45 Kamenec je minerál, dodekahydrát síranu draselno-hlinitého.

46 Nádoby byly šelakovány tzv. muzejním lakem, tedy $30 \%$ roztokem šelaku v ethanolu.

47 Formaldehyd je organická sloučenina, aldehyd kyseliny mravenčí.

48 Modrá skalice je pentahydrát síranu měd’natého. V př́rodě se nachází jako minerál chalkantit.

49 Kafr je aromatický ketonický terpen, obsažený zejména v kůře kafrovníků, pocházejících z Č́ny a Japonska. 


\section{Popisování nálezů inventárními čísly}

V současnosti je snaha popisovat kompletní nádoby na př́stupných, viditelných, ale nenápadných plochách, ideálně na dně nádoby, eventuálně na vnitřní straně střepů, kde popisky vzhledově neruší (Svobodová 2009, 39). Jednotlivé nádoby se označují čitelným nerozmazaným malým písmem, nejlépe bílou nebo černou tuší, ${ }^{50}$ rýsovacím perem o síle $0,20 \mathrm{~mm}$. Zaschlý popisek se zafixuje a chrání tenkou vrstvou bezbarvého laku (Svobodová 2010, 34). ${ }^{51} \mathrm{U}$ původních popisků nálezů ze starších sbírek často zaráží velikost písmen, nápadnost i textový obsah sdělení. Na jednom exponátu je možné se setkat i s různobarevnou kombinací popisků či kombinací různých materiálových podkladů pro popisky (obr. 10).

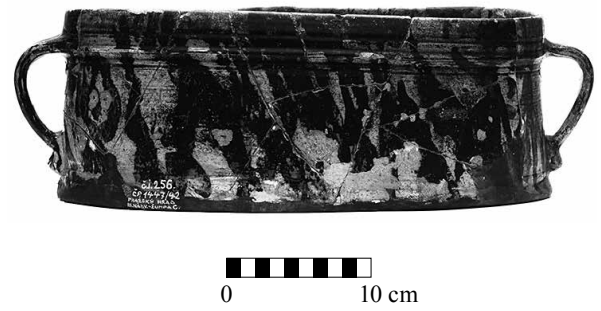

Obr. 10. Označení nádoby inventárním číslem provedené bílou olejovou barvou, Praha - Hrad, odpadní jímka C, přír. č. 1447, inv. č. 256. Foto L. Svobodová.

Abb. 10. Mit weißer Ölfarbe ausgeführte Kennzeichnung eines Gefäßes mit der Inventarnummer, Prag - Burg, Abfallgrube C, Zuwachsnr. 1447, Inv.-Nr. 256. Foto L. Svobodová.

\section{Vypracování restaurátorské zprávy}

V nedávné minulosti se sporadicky na některých pracovištích zpracovávaly konzervátorské karty, restaurátorské deníky nebo laboratorní sešity. Většinou ale restaurátoři nechtěli z konkurenčních důvodů zveřejňovat své know-how. Takové jednání dnes není akceptovatelné a již studenti se učí o významu zpráv, které musí obsahovat všechny relevantní údaje týkající se obnovy předmětu $\mathrm{s}$ důrazem na uvedení pozic doplněných částí. Dle Zákona o státní památkové péči č. $20 \mathrm{Sb}$. ze dne 30. března 1987, ve znění zákona 242/92 Sb., je povinností vypracovat ke každému ošetřenému předmětu konzervačně-restaurátorskou zprávu, jejíž nedílnou součástí jsou textové informace, fotografická dokumentace a prŕípadně ruční kresba. Restaurátorská zpráva je připojována k ošetřenému předmětu, aby bylo možné podle použitých metod, pomocných materiálů a chemikálií korigovat jeho následné uložení, veřejné prezentace, rekonzervační zákroky apod. V současnosti neexistuje standardizace restaurátorských zpráv, pouze metodické pokyny Národního památkového ústavu. ${ }^{52}$ Každá instituce si vytváří vlastní strukturu zpráv, které se archivují a jsou k dispozici nejen badatelům, ale i široké veřejnosti ve smyslu zákona ČNR č. 106/1999 Sb., o svobodném př́istupu k informacím (Svobodová 2009, 39; 2010, 34).

\section{Depozitární režim a základní metodika péče o předmět po ošetření (tzv. preventivní konzervace)}

V současnosti má většina institucí sofistikované depozitáře, v nichž je možné nastavit a udržovat tzv. depozitární režim. V prostorách s depozitárním režimem jsou udržovány optimální hodnoty relativní vlhkosti, teploty, světla a prašnosti tak, aby nedocházelo k degradaci předmětů. Keramické nálezy jsou sice považovány za jednu z nejstabilnějších komodit, nicméně restaurované předměty, které byly obnoveny za použití pomocných vnesených materiálů, vyžadují uložení v kontrolovaném prostředí. Restaurátor nese spoluodpovědnost za budoucnost předmětů tím, že podle stavu střepového materiálu a materiálů použitých při restaurování v restaurátorské zprávě nadefinuje

\footnotetext{
50 Barva tuše (bílá nebo černá) se volí dle barevného podkladu střepu.

51 Desetiprocentní roztok Paraloidu B 72 v acetonu.

52 Metodický pokyn (list) Národního památkového ústavu č. 4/2006, ze dne 4. 9. 2006, čj. NPÚ 302/6662/2006. Národní památkový ústav, ústřední pracoviště, Valdštejnské náměstí 3, 11801 Praha 1-Malá Strana (www.npu.cz, cit. 15. 2. 2015); prováděcí předpisy s komentářem).
} 
doporučené klimatické parametry uložení, ${ }^{53}$ podložené tabulkovými hodnotami z odborné literatury (Buys-Oakley 2011, 30; Kopecká a kol. 2002; Štefcová 2011, 62). Cílem tzv. preventivní konzervace je snaha předcházet budoucímu poškození. Vždy je vhodnější chránit sbírkotvorné exponáty před prudkými výkyvy klimatických podmínek, vysokou vlhkostí, ${ }^{54}$ prachem, UV zářením a škůdci, než je opakovaně čistit, přelepovat a doplňovat. Ideálem je předmět jednou profesionálně zrestaurovat a uložit do vhodného prostředí. Tím se zpomalí proces stárnutí a nevznikne problém s následnými rekonzervacemi - každý opakovaný zásah ukrajuje z komplexní hodnoty sbírkového předmětu.

\section{Závěr}

S pomocí pracovních deníků, které jsou uloženy v archivu Archeologického ústavu AV ČR Praha, v. v. i., na pracovišti Pražský hrad, a díky odbornému vyhodnocení konkrétních nálezů ošetřených v minulosti lze názorně dokumentovat rozvoj keramické restaurátorské a konzervátorské profese, a to v celém procesu od vyzvednutí (exkavace) archeologického nálezu přes jeho restaurování a konzervaci až po finální uložení do depozita či výstavních prostor. Za pomoci historických záznamů je možné porovnat rozdílné př́istupy $\mathrm{k}$ ochraně sbírkotvorných uměleckořemeslných předmětů. $\mathrm{S}$ úspěšně provedenými restaurátorskými zákroky je v současnosti neodmyslitelně spojena mezioborová spolupráce. Nezbytnou součástí kvalitně provedené restaurátorské práce je respektování etických kodexů restaurátora, které jednoznačně definují způsoby a rozsah restaurátorských zásahů. Celý restaurátorský a konzervátorský proces je zaznamenán do konzervačně-restaurátorských zpráv, které jsou nedílnou součástí práce restaurátora. Konzervačně-restaurátorské zprávy uvádějí použité metody, pomocné materiály a chemikálie, aby bylo možné korigovat podmínky uložení, veřejné prezentace a př́ípadné rekonzervační zákroky na daném předmětu. Cílem příspěvku je nejen představit práci a pracovní postupy restaurátora, ale i upozornit na nutnost úzké spolupráce s archeologem.

Př́spěvek vznikl za finanční podpory projektu Ministerstva kultury NAKI II - Technologie ošetření a identifikace degradačních procesů keramických nálezů z hradčanských paláců - Metody restaurování a konzervování pórovité i slinuté keramiky a porcelánu, DG 18P02OVV028.

\section{Př́iloha. Nejčastější etické kodexy přijímané restaurátorskou veřejností v České republice}

- Profesní etický kodex konzervátora a restaurátora ICOM-CC (Mezinárodní rady muzeí) z roku 1986. Podle ICOM je restaurátorská činnost spolu s konzervátorskou jednou ze základních etických povinností každého muzejního pracovníka, který se tím tedy zasazuje o to, aby sbírky (či jednotlivé předměty) byly $\mathrm{v}$ největším možném rozsahu zachovány pro příští generace $\mathrm{v}$ optimálním stavu, s přihlédnutím $\mathrm{k}$ současnému stupni vědomostí a finančním možnostem (ICOM [online]).

- Victoria \& Albert Museum Conservation Department Ethics Checklist (1994, 2004). Velmi kvalitní etický kodex konzervátora-restaurátora vypracovaný a užívaný ve V \& A Museum v Londýně. Každý konzervátor, než začne ošetřovat předmět, by si měl seriózně odpovědět na těchto šest otázek:

\footnotetext{
53 Jedná se o optimální klimatické podmínky, ve kterých lze zrestaurovaný keramický předmět dlouhodobě udržet v dobré kondici. Čisté, neagresivní ovzduší, v němž maximální koncentrace všech pevných a chemických polutantủ nepřesáhne $30 \mathrm{ng} / \mathrm{m}^{3}$. Limity pevných polutantů tolerovaných v depozitárních prostorách: $<75 \mu \mathrm{g} / \mathrm{m}^{3}$, ideálem je koncentrace do $50 \mu \mathrm{g} / \mathrm{m}^{3}$. Limity plynných polutantů tolerovaných v depozitárních prostorách: 5-10 ppb. Relativní vlhkost vzduchu, tolerovaný interval: $40-55 \%$ RH. Teplotní podmínky: $15-25^{\circ} \mathrm{C}$. Minimalizace účinků světla - standardní úroveň intenzity světelného záření by se měla pohybovat v rozsahu 50-250 luxů a dlouhodobě by neměla přesáhnout úroveň 300 luxů. Množství UV záření má být co nejnižší (pod $30 \mu \mathrm{W} / \mathrm{lm}$ ), v žádném případě by ale nemělo přesáhnout hodnotu $75 \mu \mathrm{W} / \mathrm{lm}$. Celková roční expozice: 100000 lx.h/rok.

54 Vysoká vlhkost je považována za jedno z největších rizik pro exponáty. Může způsobit jejich poměrné rychlé nevratné poškození. Podle současného stavu poznání je spouštěčem mikrobiologického poškození, urychluje degradaci, stárnutí, snižuje mechanickou pevnost, způsobuje deformace, praskání, změny rozměrů a optických vlastností.
} 
1) Proč vůbec přistupovat ke konzervaci, restaurování předmětu? Co je jejich důvodem?

2) Je zapotřebí konzultovat konzervaci s kolegy - konzervátory, výzkumnými pracovníky, kurátory, historiky, materiálovými specialisty?

3) Jak konzervátorský zásah ovlivní výpovědní hodnotu předmětu?

4) Povede co nejmenší konzervační zásah na předmětu k uspokojivým výsledkům? Zpomalí se proces stárnutí?

5) Co je možné očekávat po konzervaci? Jak bude pokračovat stárnutí předmětu i použitých pomocných materiálů? Jak bude vypadat př́ští konzervační zákrok vzhledem k neustálému prodlužování životnosti dochovaného předmětu?

6) Do jaké míry a jaké vnější podmínky uložení budou působit na životnost ošetřeného předmětu? (Victoria \& Albert Museum [online]).

- Dokument o profesi konzervátora-restaurátora AMG ČR. V dokumentu se praví, že jeho účelem je stanovit základní cíle, zásady a požadavky vztahující se k profesi konzervátora-restaurátora a určit roli konzervátora-restaurátora při ochraně kulturního dědictví v muzeích a galeriích České republiky. Přijatý dokument byl vytvořen $\mathrm{s}$ cílem definovat a podpořit specifický muzejní př́stup $\mathrm{k}$ ochraně předmětů kulturního dědictví (Asociace muzeí a galerií ČR [online]).

\section{Prameny a literatura}

BEKIĆ, L. et al., 2011: Conservation of Underwater Archaeological Finds Manual. International Centre for Underwater Archaeology in Zadar. Zadar.

BUYS, S.-OAKLEY, V., 2011: The Conservation and Restoration of Ceramics. Butterworth-Heinemann series in conservation and museology. London - New York.

CRONYN, J. M., 2001: The Elements of Archaeological Conservation. London - New York.

ČERMÁK, K., 1895: Strážce starožitností: povídky a poučení lidu o starožitnostech. Praha.

DENÍK, 1927-1930: Denník konservování nádob 1927-1930 26. XI. - 21. IV. Rkp. ulož. v ARÚ AV ČR, Praha, pracoviště Pražský hrad.

DENÍK 1930-1938: Prodloužení denníku, o pracích archeolog. výzkumu a prac. laboratorních na Pražském Hradě. Rkp. ulož. v ARÚ AV ČR, Praha, pracoviště Pražský hrad.

JOSEF, J., 1994: Technologie výroby keramiky. Učební text pomaturitního konzervátorského studia Národního muzea. Praha.

KOPECKÁ, I. a kol., 2002: Preventivní péče o historické objekty a sbírky v nich uložené. Státní ústav památkové péče. 25. svazek. Praha.

KRÁLÍK, M., 2004: Paleodermatoglyfika: analýza otisků prstů na pravěké keramice: teoretická východiska, metodologické problémy a praktická doporučení. Př́lohy. Disertační práce, rkp. ulož. v Ústavu antropologie PřF MU, Brno.

LOSOS, L., 1959: Muzejní práce: nové metody konservace musejních sbírek. Praha.

NEWTON, R.-DAWIDSON, S. 1989: Conservation of Glass. Butterworth Series in Conservation and Museology. Oxford.

NOVOTNÝ, J., 1894: Návod ku sbírání a zachraňování předhistorických památek. Praha.

OAKLEY, V., 2006: Ethical Considerations in the Conservation of Ceramics, Beiträge zur Erhaltung von Kust- und Kulturgut, Heft 2, 47-53.

OAKLEY, V.-KAMAL, J. K., 2002: Essentials in the Care and Conservation of Historical Ceramic Objects. London. PÁGO, L., 1985: Úvod do muzejní konzervace a restaurování. Brno.

STOCKÝ, A., 1927: Konservace musejních předmětů. Sv. 1. Praha.

RODGERS, B. A., 2004: The Archaeologist's Manual for Conservation: a Guide to Non-toxic, Minimal Intervention Artifact Stabilization. New York.

SCOTTONI, F., [online]: Restauro della Ceramica. Dostupné z: http://www.inforestauro.org/il-restauro-della-ceramica/, cit. 6. 3. 2020. 
SIGEL, T.-KOOB S. P. 1997: Conservation and Restoration under Field Conditions: Ceramics Treatment at Sardis, Turkey. Washington, DC. Dostupné z: http://www.conservation-us.org/, cit. 18. 4. 2017.

STRÁNSKÝ, Z., ed., 1976: Základy muzejní konzervace: muzeografické učební texty 2. Brno.

SVOBODOVÁ, L., 2009: Způsoby konzervování a restaurování pórovité, archeologické keramiky. In: Restaurování pórovité keramiky, odborný seminář, 12. listopadu 2009, Národní muzeum (Kotlíková, O., ed.), 26-40. Praha.

- 2010: Metodika konzervování a restaurování pórovité, archeologické keramiky, Zpravodaj STOP: časopis společnosti pro technologie ochrany památek, sv. 12, č. 4 (Kotlíková, O., ed.), 24-35.

- 2013: Zásady restaurování slinuté keramiky. In: Zdobení keramiky a porcelánu (Kalabisová, J., ed.), 103-111. Praha.

ŠTEFCOVÁ, P., ed., 2001: Preventivní ochrana sbírkových předmětů. Vyd. 2. Praha.

ZELINGER, J. et al., 1987: Chemie v práci konzervátora a restaurátora. Vyd. 2., přepracované a doplněné. Praha.

Asociace muzeí a galerií ČR [online]. Dostupné z: https://www.cz-museums.cz/web/amg/zakladni-dokumenty/dokument-o-profesi-konzervatora-restauratora, cit. 6. 3. 2020.

ICOM [online] - ICOM, international council of museums, Česká republika. Dostupné z: http://network. icom.museum/icom-czech/, cit. 6. 3. 2020.

Victoria and Albert Museum [online]. Dostupné z: https://www.vam.ac.uk/info/conservation, cit. 6. 3. 2020.

\section{Zusammenfassung}

Gewinnung von Erkenntnissen über die Entwicklung restauratorischer Techniken für Keramik anhand des Studiums der Fundtagebücher von den Grabungen auf der Prager Burg

An den in der Vergangenheit behandelten Keramikfunden lässt sich sehr anschaulich die Entwicklung des Berufes eines Keramikrestaurators dokumentieren sowie unterschiedliche Herangehensweisen zur Rettung von eine Sammlung ausmachenden kunsthandwerklichen Gegenständen vergleichen. Die Fülle an Keramikfunden erlaubt einen Vergleich zwischen den in der Vergangenheit und heute durchgeführten eigentlichen konservierenden und restauratorischen Maßnahmen anzustellen. Im Archiv des Archäologischen Instituts der Akademie der Wissenschaften der Tschechischen Republik werden an der Arbeitsstelle der Prager Burg Arbeitstagebücher aufbewahrt, in denen die Bearbeitung der Keramikfunde detailliert beschrieben werden, die von auf der Prager Burg in den Jahren 1925-1955 durchgeführten Grabungen stammen. Es handelt sich um eine einzigartige schriftliche Quelle ihrer Art, in der die Konservierungs- und Restaurierungsprozesse an konkreten Gefäßen festgehalten werden, die bis heute Bestandteil der auf der Prager Burg aufbewahrten archäologischen Sammlungen sind.

Die Restaurierung von Keramik wurde für gewöhnlich als eine leichte Aufgabe angesehen, die von jedem x-Beliebigen durchgeführt werden könne. Die heutige Praxis legt den Schwerpunkt auf die Professionalität der Keramikrestauratoren, deren fachliche Befähigung durch den Besitz einer sog. ,Restauratorenlizenz“ nachgewiesen wird, die vom Ministerium für Kultur der Tschechischen Republik erteilt wird. Der Tätigkeitsrahmen eines Restaurators wird durch ethische Kodexe gebildet.

Zwischen der Restaurierung von Keramikfunden in der Vergangenheit und der Gegenwart bestehen bisweilen himmelweite Unterschiede. Einer der größten Unterschiede ist die Dokumentation des Restaurierungsverlaufs, da seit der Verfügbarkeit von digitalen Fotoapparaten der ganze Prozess heute fortlaufend detailliert dokumentiert werden kann. Die Restaurierung eines Gegenstandes beginnt mit einer komplexen restauratorischen Untersuchung, auf deren Grundlage die Konservierungs- und Restaurierungsabsicht ausgearbeitet wird. Danach folgt die Reinigung der Keramikgegenstände, und zwar auf sog. feuchtem Weg unter Verwendung von Leitungswasser und Bürsten. In einigen Fällen kann auch von einer chemischen Reinigung Gebrauch gemacht werden. Der Grundvorgang des Klebens von Scherben hat sich nicht verändert, obgleich man davon ausgehen kann, dass jeder Restaurator dafür seine eigene Vorgehensweise hatte und auch heute noch hat (Abb. 5). Was sich jedoch ganz gewiss geändert hat, sind die verwendeten 
Klebstoffe. Gegenwärtig werden am häufigsten kommerziell erhältliche, synthetische polymere Materialien verwendet; z. B. wässrige Dispersionspolymere, Lösungsmittelsysteme, thermoplastische und thermodure Klebstoffe. Bei der Anstückung von Fehlstellen müssen mindestens $70 \%$ des ursprünglichen Gegenstandes erhalten geblieben sein, am besten im ganzen Profil. Als Füllmaterial für Fehlstellen wird ebenso wie in der Vergangenheit am häufigsten Gips verwendet, in geringerem Maße Epoxid- oder Lösungsmittelsysteme. Die Restauratoren richten sich nach den Vorgaben des Auftraggebers, ob die ergänzten Flächen gefärbt werden oder nicht. Ergänzte Fehlstellen können unter Berücksichtigung des Grundsatzes einer ethischen Konservierung farblich mit dem ursprünglichen Farbgrund vereinheitlicht werden, d.h. dass die ergänzten Stellen eine Stufe heller sein sollen, damit die Ersatzfüllungen in der Detailansicht lesbar bleiben. Eine ganzflächige Fixierung durch Verklebung der zusammengesetzten Scherben und des Füllmaterials, z.B. durch Ausgießen mit Gips, wird nicht mehr durchgeführt. Die Beschriftung der Gefäße mit Inventarnummern sollte sich nach der Regel richten, dass die Nummer auf zugänglichen, sichtbaren, jedoch unauffälligen Flächen aufgetragen wird, idealerweise am Boden eines Gefäßes, eventuell auf der Innenseite der Scherben an einer Stelle, an der die Beschriftung nicht stört.

Gemäß dem Gesetz über staatliche Denkmalpflege Nr. 20 vom 30. März 1987, Gesetzessammlung in der Fassung von Gesetz 242/92 Slg. muss zu jedem behandelten Gegenstand ein Konservierungs-, Restaurierungsbericht ausgearbeitet werden, dessen integrale Bestandteile Textinformationen, eine fotografische Dokumentation und ggf. eine Handzeichnung sind. Der Restaurierungsbericht wird dem behandelten Gegenstand beigefügt, damit es möglich ist, seine anschließende Lagerung, öffentliche Präsentation und Rekonservierungseingriffe gemäß den angewandten Methoden, Hilfsmaterialien und -chemikalien zu korrigieren. Es existiert keine Standardisierung von Restaurierungsberichten, es gibt lediglich methodische Anweisungen des Nationalen Denkmalamtes. Jede Institution schafft sich ihre eigene Berichtsstruktur, die archiviert wird und nicht nur Forschern, sondern auch der breiten Öffentlichkeit im Sinne des Gesetzes des Tschechischen Nationalrats Nr. 106/1999 Slg. über den freien Zugang zu Informationen zur Verfügung steht.

Die meisten Institutionen haben ausgeklügelte Depots zur Verfügung, in denen es möglich ist, eine sog. Depotordnung aufzustellen und einzuhalten. In den Räumen, in denen die Depotordnung gilt, werden die Optimalwerte für Luftfeuchte, Temperatur, Licht und Staubentwicklung so eingehalten, damit es zu keiner Degradation der Gegenstände kommt. Keramikfunde werden zwar zu den stabilsten Waren gezählt, nichtsdestotrotz erfordern restaurierte Gegenstände eine Lagerung in einer kontrollierten Umgebung.

Der vorliegende Beitrag entstand unter finanzieller Förderung des Projektes des Kulturministeriums NAKI II - Technologien der Behandlung und Identifizierung von Degradationsprozessen bei Keramikfunden aus den Palais der Prager Burg - Methoden der Restaurierung und Konservierung von poröser und gesinterter Keramik und Porzellan, DG 18P02OVV028.

Mgr. Gabriela Blažková, Ph.D., Archeologický ústav AV ČR, Praha, v. v. i., Letenská 4, 11801 Praha 1 , Česká republika, blazkova@arup.cas.cz

Ljuba Svobodová, Archeologický ústav AV ČR, Praha, v. v. i., Letenská 4, 11801 Praha 1, Česká republika, svobodova@arup.cas.cz 
